\title{
EFFECTIVENESS OF VEGETATION IN EROSION CONTROL FROM FOREST ROAD SIDESLOPES
}

\author{
J. M. Grace III
}

\begin{abstract}
Forest roads have been identified as the major contributor to sediment production from forested lands, accounting for perhaps as much as $90 \%$ of all sediment produced. In recent years, increased concern and societal pressure has focused on the impacts of forest roads and the effectiveness of erosion control measures. In addition, the re-introduction of native species for erosion control has become a priority on many forestlands. This study evaluates the effectiveness of a wood excelsior erosion mat, native species vegetation, and exotic species vegetation treatments in erosion control from forest road sideslopes in the Talladega National Forest in Alabama over a 4-year period. In comparison to bare soil control plots, treatments significantly reduced sediment and runoff yield from the road sideslopes. Mean sediment yield from the native species vegetation, exotic species vegetation, and erosion mat treatments were $1.1,0.45$, and $0.80 \mathrm{~g} \mathrm{~m} \mathrm{~m}^{-2} \mathrm{~mm}^{-1}$, respectively. The native species vegetation was as effective as the exotic species vegetation and erosion mat in reducing sediment yield from the forest road sideslopes.
\end{abstract}

Keywords. Soil erosion, Ground cover, Slopes, Surface runoff, Conservation.

$\mathrm{F}$ lorest roads affect forest management on the nation's public lands as well as state, industry, and private land holdings. The Forest Service road system alone is more extensive than the U.S. Interstate Highway System, consisting of over $600,000 \mathrm{~km}$ traversing the National Forests (Copstead, 1997). The forest road system, cited as the major source of sediment from forestlands, presents the greatest potential for adverse impacts on water quality on forestlands (Megahan, 1972; Pope, 1977; Yoho, 1980).

Undisturbed forestlands have minimal erosion and sedimentation due to good surface cover from trees and understory, which protects the soil surface from damaging storm energy. Surface cover provides dissipation of the energy associated with raindrop impact, which can dislodge soil particles (Wischmeier and Smith, 1958). Forest floor litter, debris, and increased surface roughness provide for increased infiltration and decreased runoff to transport detached soil particles. Disturbed forest conditions are common in the U.S. due to the increased demand for forest products, which began in the 1950s during a period of intensive use.

In recent years, the impact of management activities for watershed health on the nation's public lands has been highlighted because soil erosion and stream sedimentation

Article was submitted for review in July 2001; approved for publication by the Soil \& Water division of ASAE in March 2002.

An extended abstract of the manuscript was published as a conference paper by the ASAE-sponsored International Symposium: Soil Erosion for the 21st Century.

The author is Johnny McFero Grace III, ASAE Student Member Engineer, Research Engineer, Forest Operations Research to Achieve Sustainable Management, Southern Research Station, USDA Forest Service, G. W. Andrews Forestry Sciences Lab., 520 Devall Drive, Auburn, Alabama 36830; phone: 334-826-8700; fax: 334-821-0037; e-mail jmgrace@fs.fed.us. adversely affect the nation's water quality (Authur et al., 1998; Binkley and Brown, 1993; Megahan et al., 1991). Forest management operations such as timber harvesting, thinning, site preparation, and road construction and maintenance can result in nutrient removal or relocation, transport of pesticides, road impairment, and stream degradation. Disturbed forestlands also have accelerated erosion losses as a result of forest management activities (Binkley and Brown, 1993; Shepard, 1994; Walbridge and Lockaby, 1994).

Forest roads are considered the most detrimental forest management operation to forest soil and water quality, perhaps accounting for $90 \%$ of sediment yield from forestlands (Megahan, 1972, 1974). Sediment from roads is often transported directly to stream systems, causing environmental damage by clogging spawning beds (Packer, 1967). Forest road management is a major area of potential adverse impacts from road construction and maintenance procedures on forested lands that disturb the forest floor and cover (Binkley and Brown, 1993; Reid and Dunne, 1984). Forest roads have increased potential for soil detachment and transport, attributable to several factors: (1) elimination of vegetative cover, (2) destruction of natural soil structure, (3) increased compaction, (4) increased slope, (5) interception of surface and subsurface flow, and (6) concentrated flow. The increased erosion potential of forest roads requires special design considerations to reduce the environmental impacts on surface water quality.

The initial problems associated with erosion losses from the road sideslopes were reported during the 1930s. Hursh (1939) investigated road sideslope stabilization alternatives in the Southern Appalachian region and concluded that mulching is a simple, inexpensive, and guaranteed method to establish vegetative cover and thereby control erosion losses. Expanding on this initial work, Hursh (1942) reported that stabilization of road sideslopes requires a coordination of engineering and vegetation establishment efforts. The research concluded that planning and location of roads has a 
major influence on sideslope stabilization, and that the establishment of vegetation on road sideslopes at reasonable cost reduces future maintenance expenses.

Based on studies showing high sediment yields during the first year after forest road construction in Idaho, Megahan and Kidd (1972) suggested several requirements to control surface erosion and sediment export downslope: (1) immediate application of erosion control techniques, (2) surface cover until vegetation establishment, and (3) use of debris barriers to reduce sediment export downslope.

Burroughs and King (1989) investigated erosion from each component of the road prism, including traveled ways, fillslopes, cutslopes, and roadside ditches. The investigators looked at six different erosion control treatments on fillslopes: straw with asphalt tack, straw with a net or mat, straw alone, erosion control mats, wood chips or rock, and hydromulch. Their results showed a direct correlation between the amount of ground cover and the effectiveness of erosion control, and that the most effective treatment was straw with asphalt tack.

Alternative road design characteristics have been presented to control the environmental impact of the forest road (Cook and Hewlett, 1979; Gardner, 1978; Kochenderfer and Helvey, 1987; Nagygyor, 1984; Packer, 1967; Swift, 1985). Foremost in road design criteria is the control of surface water to mitigate erosion losses. Sediment transport distances downslope depend greatly on the energy of the surface water and the characteristics of the flow path. Reducing the energy of surface water can greatly reduce the erosion process (soil particle detachment and transport).

As a result of road prism erosion research, forest managers commonly apply erosion control techniques to all components of the road prism and attempt to ensure that adequate filter strip widths are in place to filter runoff before it reaches streams. However, the capacity of the forest floor to filter sediment-laden runoff is not boundless and can be expected to decrease as transported sediment accumulates. A renewed focus by the USDA Forest Service on road designs to minimize adverse impacts such as soil erosion, sedimentation, and costs has initiated investigations to define environmentally, socially, and economically sustainable alternatives. The utilization of native species for erosion control is one alternative that could address the objectives of this new focus.

The environmental impacts associated with forest roads demand progress in erosion control from these sensitive systems while still providing access for forest management activities. Clearly, vegetation establishment has been presented as an elemental component to controlling erosion loss from sensitive road systems. Exotic species are typically selected for their availability and reliable establishment. However, native species may be desired ecologically. Effective comparisons of erosion control benefits of native and exotic species are critical for informed erosion control management decisions.

This study evaluates the effect of erosion control treatments (specifically native species vegetation) on forest road sideslope erosion. A better understanding of the relationship between soil erosion dynamics and vegetation establishment will help promote economically and environmentally sensitive access systems for sustainable forest management. The objective of this study was to test the hypothesis that there are no differences in the sediment yield from two commonly applied erosion control treatments, native species vegetation, and a bare soil control.

\section{MeTHODS}

A field experiment was conducted to determine the effect of three erosion control techniques on forest road sideslopes in central Alabama (Grace, 1999; Grace et al., 1998). The study road, a mid-slope half-bench crowned road with inside ditching that traverses a west-facing slope, was constructed in 1995 on the Shoal Creek District of the Talladega National Forest in Cleburne County near Heflin. Road construction featured 2.2:1 cutslopes and 1:1 fillslopes. The soils on the site were of the Tatum series, a fine-loamy mixed-thermic Typic Hapudult.

In September 1995, 12 small plots, each $1.5 \times 3.1 \mathrm{~m}$, were established on both a cutslope and a fillslope with homogenous slope, soils, and slope length. Plots were installed so that treatment areas were isolated from the surrounding slope. On three sides of each plot, 20-cm high borders were driven $5 \mathrm{~cm}$ into the soil surface to exclude runoff from the surrounding slope. A collection gutter at the bottom of each plot routed plot runoff to a $130-\mathrm{L}$ sediment tank, pre-calibrated to measure runoff volume.

A randomized complete block design was used to evaluate the effectiveness of three erosion control techniques on sediment and runoff yield. Each of three blocks on each slope consisted of a replicate of each of the three treatment plots in the investigation. The three treatments were a native species mixture, an exotic species mixture, and a wood excelsior erosion mat. The native species mixture was big bluestem (Andropogon gerardii), little bluestem (Andropogon scoparius), and Alamo switch grass (Panicum virgatum), each applied at a rate of $11 \mathrm{~kg} \mathrm{ha}^{-1}$. The exotic species mixture, typically applied by the National Forests of Alabama on road sideslopes, consisted of Kentucky 31 tall fescue (Festuca arundinecea) applied at $28 \mathrm{~kg} \mathrm{ha}^{-1}$, Pensacola bahiagrass (Paspalum notatum) applied at $23 \mathrm{~kg} \mathrm{ha}^{-1}$, annual lespedeza (Lespedeza cuneata) applied at $6 \mathrm{~kg} \mathrm{ha}^{-1}$, and white clover (Trifolium repens) applied at $11 \mathrm{~kg} \mathrm{ha}^{-1}$. Erosion mat treatments were seeded with the exotic species mixture and covered with a wood excelsior erosion mat. Treatments were hand mulched with fescue hay at a rate of $4.5 \mathrm{t} \mathrm{ha}^{-1}$ and fertilized at the recommended rate of $1.0 \mathrm{t} \mathrm{ha}^{-1}$ with 13-13-13 fertilizer. The control, expected to have natural regeneration, had no fertilizer, mulch, or seeding applications.

An on-site rain gauge recorded precipitation amounts and intensity during the 4-year study period. The frequency of the data collection events, which usually contained several storm events, varied from 1 to 12 weeks depending on the time required to fill the sediment tanks. Data collection began with recording runoff volume after measuring its depth in the pre-calibrated sediment tank. Suspended sediment was measured by collecting $500 \mathrm{~mL}$ grab samples of the stored runoff and processing them for gravimetric analysis in accordance with methods defined by Greenberg et al. (1992). All deposited sediment was collected after drainage of the stored runoff. At the laboratory, deposited sediment was air-dried and then oven-dried at $105^{\circ} \mathrm{C}$ to moisture content of $1 \%$ or less (dry basis). Total sediment yield from each plot was the combination of suspended and deposited sediment fractions collected. Eighteen inspections of ground cover 
consisted of classifying 100 random points within each plot as either covered or bare. The sum of vegetation and mulch cover was taken as the percent ground cover for each plot.

Sediment and runoff yield responses were tested by SAS GLM repeated measures procedures as functions of the treatment effects, with time as the repeated measure (SAS, 1988). The variables that were considered to influence the responses were precipitation amount and intensity, treatment method, and cover condition. Individual treatment mean values were tested for significance $(\alpha=0.05)$ where repeated measures ANOVA indicated significant differences.

\section{RESUlTS AND DisCuSSION}

Although observed precipitation on the study site varied during the 4 study years (fig. 1), variation was not significant until year 4. To correct any influence of precipitation differences on sediment and runoff yield, analysis of sediment and runoff concentrated on yield per unit depth of precipitation instead of overall yield.

Treatment method strongly influenced ground cover during the first year following treatment application. The erosion mat treatment provided $100 \%$ cover immediately after installation and had an overall mean cover of $95 \%$ over the study period (table 1). The vegetative treatments gave less cover immediately after installation, with cover averaging $52 \%$ for the exotic species and $70 \%$ for the native species. However, ground covers had increased to $85 \%$ for the exotic species and $93 \%$ for the native species by the end of the study period. Overall mean ground cover for native species and exotic species during the study period was $75 \%$ and $72 \%$, respectively. The bare soil control plots, allowed to re-vegetate naturally, had an overall mean ground cover of $13 \%$ over the study period. All ground covers tested were found to have statistically greater cover $(\mathrm{P}<0.05)$ than the control plots (table 1). Average ground cover for the bare soil controls reached a maximum cover of only $30 \%$ by the end of the 4-year period. Repeated measures ANOVA detected treatment effects on ground cover during the study period. Contrasts tests identified the erosion mat and the bare soil control as statistically different $(\alpha=0.05)$ from the vegetative treatments, but there was no significant difference between the exotic and native species treatments (table 1).

Data suggest that the amount of ground cover, a variable influenced by treatment method, influenced both sediment

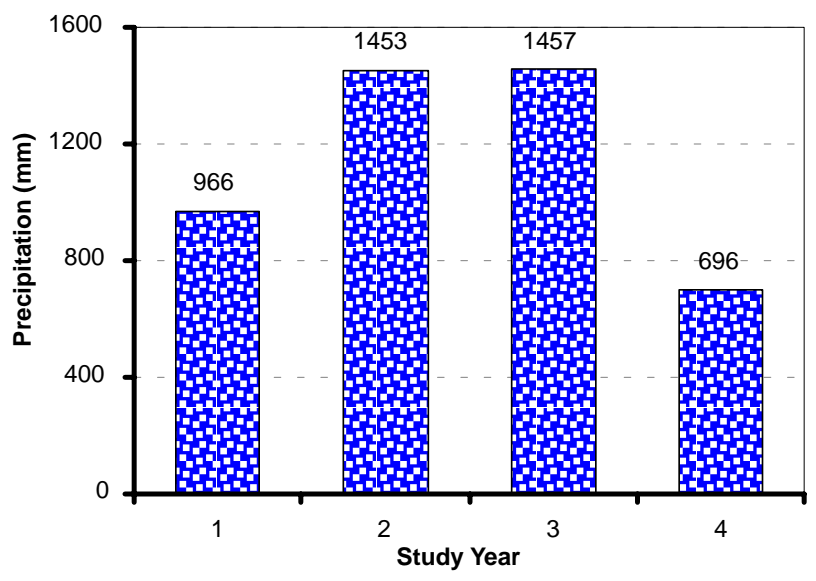

Figure 1. Observed precipitation during each study year.
Table 1. Mean ground cover and significance of contrast tests for erosion control treatments during the study period.

\begin{tabular}{lccc}
\hline & $\begin{array}{c}\text { Ground } \\
\text { Cover } \\
(\%)\end{array}$ & F-Value & Pr $>$ F \\
\hline Treatment & 13 & & \\
\hline Control & 95 & 215.72 & $<0.0001^{[\mathrm{a}]}$ \\
Erosion mat & 75 & 149.84 & $<0.0001^{[\mathrm{a}]}$ \\
Native species & 72 & 12702 & $<0.0001^{[\mathrm{a}]}$ \\
Exotic species & & & \\
\hline Contrasts & & 5.99 & $0.02^{[\mathrm{b}]}$ \\
Erosion mat vs. native species & & 11.68 & $0.003^{[\mathrm{b}]}$ \\
Erosion mat vs. exotic species & & 0.94 & $0.3^{[}$ \\
Native vs. exotic species & & & \\
\hline
\end{tabular}

[a] Significance of results as compared to the control, ANOVA results between treatments (using repeated measures analysis).

[b] Significant at the 0.05 level of probability.

and runoff yields. Previous research has concluded that ground cover reduces sediment and runoff yield by intercepting raindrops and filtering runoff. Confirming the inverse relationship reported by Swift (1984a) and Michael et al. (2000), a covariate analysis showed moderate negative correlations of -0.58 between ground cover and sediment yield and -0.46 between ground cover and runoff yield.

This analysis can only consider sediment and runoff yields during the first six months of the first year due to data loss. Total sediment yield during the first year would likely have been greater with the inclusion of lost data. Consistent with previous studies (Dudeck et al., 1970; Swift, 1984b), sediment yield during the first six months of this study period was significantly greater than all other periods of the study. On average, $70 \%$ of sediment yield from treatments was observed during the abbreviated first study year (figs. 2 and 3). Sediment yields initially increase at a much greater rate during the first period but increase at a decreasing rate thereafter. In contrast, the control exhibited a lower percentage of sediment yield during the first year (50\%), but this was because of its continued high erosion losses throughout the study. Bare soil controls, without the protection of vegetation or mulch, exhibited accelerated erosion losses due to exposure to the erosive energy of raindrops. Compared to the bare soil control, vegetative treatments resulted in sediment yield reductions of greater than $70 \%$ for all treatments during the establishment period (Grace et al., 1998).

Repeated measures ANOVA detected significant time and time*treatment interaction effects on sediment yield per unit precipitation depth in the investigation. The bare soil control sediment yield, with an overall mean of $2.7 \mathrm{~g} \mathrm{~m}^{-2} \mathrm{~mm}^{-1}$ $\left(0.03 \mathrm{t} \mathrm{ha}^{-1} \mathrm{~mm}^{-1}\right)$, was significantly greater than the vegetative treatments. All vegetative treatments were statistically similar, with means of $1.1 \mathrm{~g} \mathrm{~m}^{-2} \mathrm{~mm}^{-1}\left(0.011 \mathrm{t} \mathrm{ha}^{-1}\right.$ $\left.\mathrm{mm}^{-1}\right)$ for native species, $0.45 \mathrm{~g} \mathrm{~m}^{-2} \mathrm{~mm}^{-1}\left(0.005 \mathrm{t} \mathrm{ha}^{-1}\right.$ $\left.\mathrm{mm}^{-1}\right)$ for exotic species and $0.80 \mathrm{~g} \mathrm{~m}^{-2} \mathrm{~mm}^{-1}\left(0.008 \mathrm{t} \mathrm{ha}^{-1}\right.$ $\mathrm{mm}^{-1}$ ) for the erosion mat. Over the 4-year study period, soil loss from the vegetative treatments declined to less than $0.05 \mathrm{t} \mathrm{ha}^{-1} \mathrm{yr}^{-1}$. In contrast was the control with soil loss of $4 \mathrm{tha}^{-1} \mathrm{yr}^{-1}$. The statistical similarity of the treatments and consistently greater sediment yields for all samplings of the control suggest that vegetation establishment is critical in erosion control.

Treatment effects were also detected for runoff yield using repeated measures ANOVA. Consistent with the sediment yield results, significant time and time*treatment interaction 




'Cumulative sediment yields after year 1 do not include soil loss during the period of missing data

Figure 2. Cutslope cumulative sediment yield during the 4-year study period.

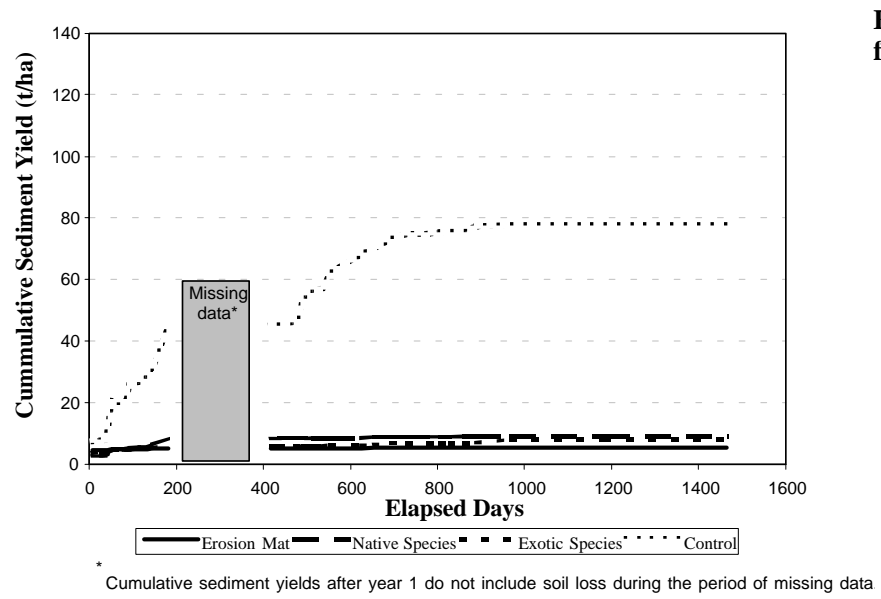

Figure 3. Fillslope cumulative sediment yield during the 4-year study period.

effects were observed in the analysis. Contrast tests for between-subject effects showed that all treatments had significantly different overall mean runoff yields, with the bare soil control yielding the greatest mean runoff of $36.3 \mathrm{~mm}$. The control runoff yield remained relatively constant throughout the study period, while runoff yield from treatments decreased following the initial establishment period (figs. 4 and 5). The native species and the exotic species had the next two greatest mean runoff yields: 22.8 and $16.6 \mathrm{~mm}$, respectively. The erosion mat treatment exhibited the least runoff yield, with $7.2 \mathrm{~mm}$ equivalent runoff depth. Runoff yield, consistent with previous literature, increased as the percent ground cover decreased (Burroughs and King, 1989; Swift, 1984a).

\section{Summary AND CONClusions}

Sediment yields were significantly reduced by all treatments used in this investigation. Over the 4-year study period, the erosion mat, exotic species, and native species treatments were not statistically different in sediment yield, although differences were detected in runoff yield. Reductions greater than $70 \%$ of total soil losses from treatments were observed during the first six months of the study period (Grace et al., 1998). The bare soil control had greater sediment and runoff yield than all treatments for the duration

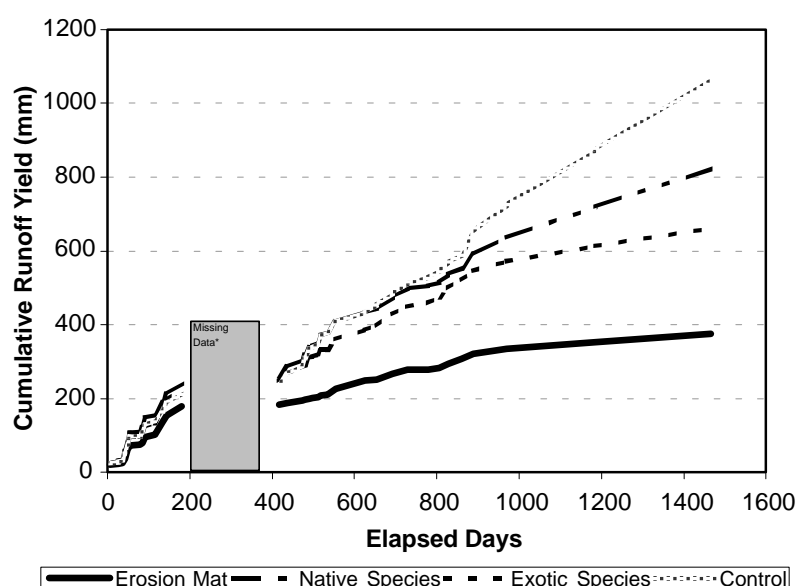

${ }^{*}$ Cumulative runoff yields after year 1 do not include runoff during the period of missing da

Figure 4. Cutslope cumulative runoff yield during the 4-year study period for treatments and control.

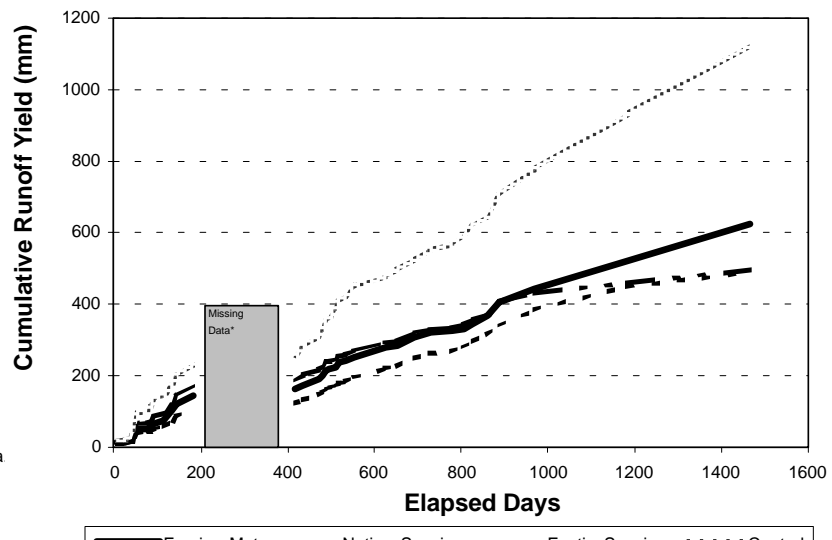

-Erosion Mat - - Native Species - - - Exotic Species - -......" Control

Figure 5. Fillslope cumulative runoff yield during the 4-year study period for treatments and control.

of the study. The accelerated yields observed for the control can be attributed to the lack of ground cover to protect soil from raindrop impact and overland flow. Ground cover was determined as moderately correlated with sediment and runoff yield, which could have been expected due to the energy dissipation characteristics of ground cover.

Surface cover and early vegetation establishment are necessary elements in controlling erosion losses from slopes following a disturbance. Exotic species vegetation is commonly preferred to native species vegetation to control erosion from forest road sideslopes primarily due to reduced application costs, reliable establishment, and quick cover (Grace et al., 1998). However, proponents of native species may prefer ecological and long-term stabilization benefits of native species vegetation, which include reduced soil erosion, increased biological diversity, and maintenance costs savings (Patchett, 2000). For instance, increased costs of native species vegetation seed may be offset by long-term maintenance cost savings.

Based on the results of this investigation, native species vegetation offer similar erosion control benefits to that of exotic species vegetation and the wood excelsior erosion mat. The findings suggest that the selection of exotic species 
over native species vegetation is not justified based on erosion control benefits. The equally effective erosion control qualities of native species vegetation may justify re-introduction priorities on many forestlands. However, management decisions on the selection of exotic species, native species, or erosion mats will likely be based on economic, ecological, and social considerations.

Erosion following road construction, as with most operations that disturb the soil surface, can result in accelerated soil loss without appropriate control measures (Megahan et al., 1991). Ground surface cover has been accepted as a minimal requirement in forest management (Best Management Practices) to mitigate the effect of road construction (Alabama Forestry Commission, 1993). Surface cover and early vegetation establishment are necessary elements in controlling erosion losses from slopes following a disturbance. This is especially true for steep sideslopes of roads, where construction has greater potential for accelerated erosion losses than any other management activity. Unfortunately, the road construction process often results in sideslopes that are devoid of vegetation and unprotected from raindrop splash and concentrated surface flow.

\section{ACKNOWLEDGEMENTS}

This project was significantly supported by the efforts and cooperation of the National Forests of Alabama, Shoal Creek District. The author would like to acknowledge the valuable contribution of Mr. Preston Steele, Southern Research Station of the USDA Forest Service, in the site maintenance and data compilation for this work.

\section{REFERENCES}

Alabama Forestry Commission. 1993.Alabama's Best Management Practices for Forestry. Montgomery, Ala.: Alabama Forestry Commission

Authur, M. A., G. B. Coltharp, and D. L. Brown. 1998. Effects of best management practices on forest streamwater quality in Eastern Kentucky. J. American Water Resources Association 34(3): 481-495.

Binkley, D., and T. C. Brown. 1993. Forest practices as nonpoint sources of pollution in North America. Water Resources Bulletin 29(5): 729-740.

Burroughs, E. R., Jr., and J. G. King. 1989. Reduction of soil erosion on forest roads. INT-264. Ogden, Utah: USDA Forest Service, Intermountain Research Station.

Cook, W. L., Jr., and J. D. Hewlett. 1979. The broad-based dip on Piedmont woods roads. Southern J. Applied Forestry 3(1): 77-81.

Copstead, R. 1997. Summary of historical and legal context for water/road interaction. San Dimas, Calif.: USDA Forest Service, San Dimas Technology and Development Center.

Dudeck, A. E., N. P. Swanson, L. N. Mielke, and A. R. Dedrick. 1970. Mulches for grass establishment on fill slopes. Agronomy J. 60(6): 810-812.

Gardner, R. B. 1978. Some environmental and economic effects of alternative forest road designs. Trans. ASAE 22(1): 63-68.

Grace, J. M., III. 1999. Erosion control techniques on forest road cutslopes and fillslopes in North Alabama. In Proc.Seventh International Conference on Low-Volume Roads: Volume 2. Transportation Research Record 1652, 227-234. Washington, D.C.: National Research Council, Transportation Research Board.
Grace, J. M., III, B. Rummer, B. J. Stokes, and J. Wilhoit. 1998. Evaluation of erosion control techniques on forest roads. Trans. ASAE 41(2): 383-391.

Greenberg, A. E., L. S. Clesceri, and A. D. Eaton, ed. 1992. Standard Methods for the Examination of Water and Wastewater. 18th ed. Washington, D.C.: American Public Health Association.

Hursh, C. R. 1939. Road bank stabilization at low cost. Technical Note 38. Asheville, N.C.: USDA Forest Service, Southeastern Forest Experiment Station.

1942.The naturalization of roadbanks. Technical Note 51. Asheville, N.C.: USDA Forest Service, Southeastern Forest Experiment Station.

Kochenderfer, J. N., and J. D. Helvey. 1987. Using gravel to reduce soil losses from minimum-standard forest roads. J. Soil and Water Conservation 42(1): 46-50.

Megahan, W. F. 1972. Logging, erosion, sedimentation: Are they dirty words? J. Forestry 70(5): 403-407.

1974. Erosion over time on severely disturbed granitic soils: A model. Research Paper INT-156. Ogden, Utah: USDA Forest Service, Intermountain Forest and Range Experiment Station.

Megahan, W. F., and W. J. Kidd. 1972. Effect of logging roads on sediment production rates in the Idaho Batholith. Research Paper INT-123. Ogden, Utah: USDA Forest Service, Intermountain Forest and Range Experiment Station.

Megahan, W. F., S. B. Monsen, and M. D. Wilson. 1991. Probability of sediment yields from surface erosion on granitic roadfills in Idaho. J. Environ. Quality 20(1): 53-60.

Michael, J. L., H. L. Gibbs, J. B. Fischer, and E. C. Webber. 2000. Protecting surface water systems on forest sites through herbicide use. In Xth World Water Congress Proc.: Water, The World's Most Important Resource, CD-ROM. 12-17 March 2000. Melbourne, Australia: International Water Resources Association.

Nagygyor, S. A. 1984. Construction of environmentally sound forest roads in the Pacific Northwest. In Proc. 1984 COFE/IUFO Conference, 143-147. Orono, Maine. 12-14 August. Orono, Maine: University of Maine.

Packer, P. E. 1967. Criteria for designing and locating logging roads to control sediment. Forest Science 13(1): 2-18.

Patchett, J. 2000. Integrating native landscapes. Land and Water 44(5): 44-47.

Pope, P. E. 1977. Water quality and forestry: A review of water quality legislation and the impact of forestry practices on water quality. Station Bulletin No. 161. West Lafayette, Ind.: Purdue University, Department of Forestry and Natural Resources.

Reid, L. M., and T. Dunne. 1984. Sediment production from forest road surfaces. Water Resources Research 20(11): 1753-1761.

SAS. 1988. SAS Procedures Guide, Release 6.03 edition. Cary, N.C.: SAS Institute, Inc.

Shepard, J. P. 1994. Effects of forest management on surface water quality in wetland forest. Wetlands 14(1): 18-26.

Swift, L. W., Jr. 1984a. Gravel and grass surfacing reduces soil loss from mountain roads. Forest Science 30(3): 657-670.

1984b. Soil losses from roadbeds and cut and fill slopes in the southern Appalachian Mountains. Southern J. Applied Forestry 8(4): 209-215.

1985. Forest road design to minimize erosion in the southern Appalachians.In Proc. Forest and Water Quality: A Mid-South Symposium, 141-151. B. G. Blackman, ed. 8-9 May. Little Rock, Ark.: University of Arkansas.

Walbridge, M. R., and B. G. Lockaby. 1994. Effects of forest management on biogeochemical functions in southern forested wetlands. Wetlands 14(1): 10-17.

Wischmeier, W. H., and D. D. Smith. 1958. Rainfall energy and its relationship to soil loss. Trans. American Geophysical Union 39(2): 285-291.

Yoho, N. S. 1980. Forest management and sediment production in the South: A review. Southern J. Applied Forestry 4(1): 27-36. 